\title{
THE INSECTICIDAL ACTION AND TOXICOLOGY OF CARBARYL
}

\author{
A. J. REEVES \\ Ivon Watkins Ltd., New Plymouth
}

Summary

Carbaryl was developed in the research laboratories of Union Carbide. It is a synthetic organic compound belonging to the carbamate group. As an insecticide it displays a wide range of activity, moderate speed of action, and extencled residual properties. It is safe to handle and mainly non-toxic to plants, although in some cases beneicial fruit thinning occurs. It is effective against insects which have developed resistance to other insecticides, and is commercially available.

\section{INTRODUCTION}

A MOST SIGNIFICANT FACTOR in the future of carbaryl is associated with the increasing legal restrictions on pesticide residues in treated plant and animal products, and hence on the use of insecticides on both pasture and fodder crops. The recent Agricultural Chemicals Act is an example of the limitations being imposed. Carbaryl has not, through test, caused any worry as far as milk contamination is concerned. This has already been recognized by its release by the U.S.D.A. and by the Food, Drug and Cosmetics Act, which enables a 100 p.p.m. tolerance rating for carbaryl use on forage crops, such as lucerne and pasture.

In 1959, Union Carbide received its first tolerance for food crops and carbaryl was labelled for use on several crops. This followed the extensive work during the 1954-55-56 experimentation and development period.

The first samples of carbaryl were placed outside the United States in 1958. They showed promising results, for example in the control of leaf hoppers on rice in Japan. Experimental sales began in 1959 and registrations were issued in many countries.

Every insecticide, new or old, has its limitations. Carbaryl has two - the lack of a commercially acceptable emulsifiable concentrate, and the compound's inefficiency against mites, such as the red mite (Tetranychus spp.), which is well known in New Zealand. Mite control is a most pressing problem, and it is unfortunate that carbaryl, like so many pesticides, cannot contribute a solution.

\section{RANGE OF EFFECTIVENESS}

Studies on the insecticidal action of carbaryl are not complete, but there is no disputing the fact that it is a cholinesterase inhibitor on insects. It is not effective as a fungicide or a bactericide. It does have some herbicidal action, but this is only at very high dosages, i.e., $10 \mathrm{lb}$ a.i. per acre and above. When used for the control of earthworms in bowling greens, high rates of application $(20 \mathrm{lb}$ of the $50 \%$ formulation) mixed with fertilizer have brought about the death of such grasses as Poa annua and young seedling grasses. From a practical standpoint, however, it is not herbicidal.

Carbaryl, according to American literature, appears to be effective against some roundworms when they are animal parasites and it is fed to the animal, but it is not effective against all parasitic nematodes. Against earthworms there was originally a response 
from carbaryl dosages of $20 \mathrm{lb}$ or more a.i. per acre, but during work in New Zealand on bowling and golf greens use of a maximum of $61 / 2 \mathrm{lb}$ a.i. per acre brought about adequate control, so much so that earthworms have not been a problem in those greens for 12 months. This earthworm response, however, compares roughly with the response from compounds like chlordane.

Against molluscs, carbaryl seems to have a fair degree of activity. The data from numerous test on slugs and snails attacking vegetation show that carbaryl compares with metaldehyde in some tests, but does not seem to have residual properties sufficient to place it on the market as a separate product for the control of these pests. However, work is being undertaken at present to evaluate the control and residual effects of the combination of metaldehyde and carbaryl for control of molluscs. Against the arthropods, carbaryl is quite effective. Against crustaceans, control has been obtained and there has been a certain response from the marine crabs. It is moderately effective against spiders and highly active against ticks.

The United States provides no information on the control of mites which are parasitic on animals, such as the sarcoptic and dermodectic mites, and it does not control the New Zealand red spider mite.

Occasionally some depression of the European red mite is observed, but there is no response from the two-spotted spider mite. Results of laboratory and field tests on other insects differ by Order and Family. Listed below is a summary of the results so far obtained:

Orthoptera: Quite susceptible.

Fair control of crickets (Acheta commodus) has been obtained at rates of 1 to $2 \mathrm{lb}$ a.i. per acre, but the residual effect is not very long, and of no consequence.

Dermaptera: Very effective against earwigs.

Isoptera (termites): No control.

Hemiptera (bed bugs): Good control of many groups.

Homoptera (aphids, scale insects): Control of white flies (Trialeurodes vaporariorum), San Jose (Quadraspidiotus perniciosus) and 'Parlatoria scale has been obtained. Some aphid species are susceptible, some are not.

Lepidoptera: Effective against many Families of this Order, which includes such insects as the army worm (Pseudaletia separata), potato tuber moth (Gnorimoschema operculella), white butterfly (Pieris rapae), diamond-back moth (Plutella maculipennis), etc.

Coleoptera (beetles and weevils): Effective against many families.

Hymenoptera (bees and wasps): Generally effective against this Order, with the exception of some of the ants. Toxic to bees.

Diptera: Practically no response against house flies, but good control of the biting-fly of cattle. Variable results on mosquitoes.

It has often been asked whether carbaryl is most effective against the egg, the immature stage, or the adult. With the Mexican bean beetle in the United States, for example, good control of the larva and the adult is obtained with one unit of carbaryl. For the control of the egg, three units are needed; for the control of the pupa, almost fifteen. A unit could be $0.5 \mathrm{lb}$ of formulated material per 100 gal. This is an approximation of the relative effectiveness against 
different stages. Carbaryl is effective against the coding moth adult at rates that are normally used for the control in the field, namely 0.75 to $1 \mathrm{lb}$ of $80 \%$ formulation per $100 \mathrm{gal}$ of water, and these dosages also kill the hatching larvae. The effect on eggs is not believed to be quite as good as the action against the adult or larvae. Table 1 gives the susceptibility and the action of carbaryl against the adult oriental fruit moth (Grapholitha molesta) which can be seen to be more susceptible than the egg or the larvae.

TABLE 1: PER CENT. MORTALITY OF ORIENTAL FRUIT MOTH (GRAPHOLITHA MOLESTA)



SPEED OF ACTION

The speed of almost any insecticide depends on two factors - how much is being used, and against what insects?

Figure 1 shows the speed of action of three insecticides, carbaryl dieldrin and demeton-o-methyl, against the boll weevil (Anthonomus grandis). They were tested at two different levels, 200 and $2 \mathrm{mg}$ per sq. $\mathrm{ft}$, in the laboratory. At high levels a very rapid kill is obtained with dieldrin and also with demeton-o-methyl, whereas carbaryl is relatively slow, but at $1 / 100$ th the concentrations there is practically no change in the carbaryl curve, while the action of the other materials becomes much slower. It is believed that this property of carbaryl, the ability to control at low levels, may be responsible for the effectiveness under field conditions where low residues would not be expected to prove effective.

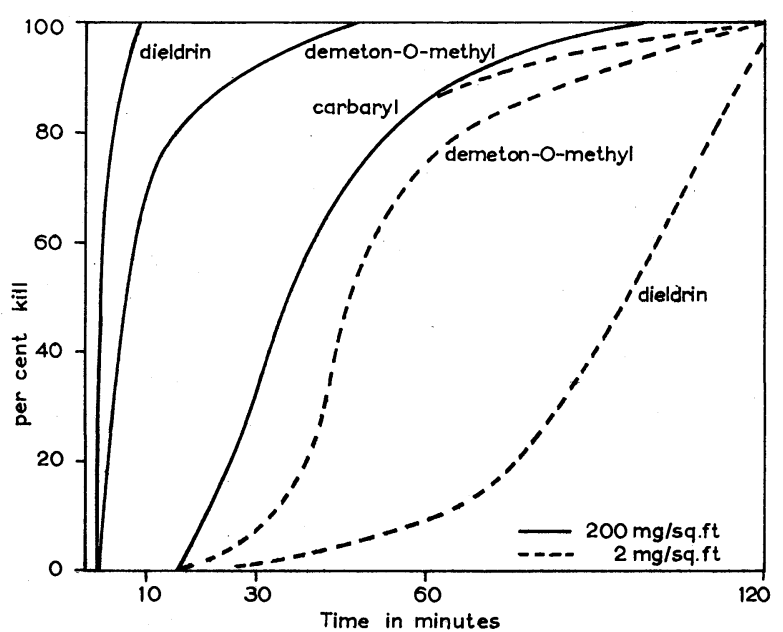

Fig. 1: Speed of action of carbaryl against Anthonomus grandis.

To summarize the information on the speed of action, it can be said that carbaryl is approximately as fast as most of the chlorinated hydrocarbons, perhaps a little faster than some, and slower than most of the organic phosphates, a feature borne out in the 1961-62 
season when carbaryl was used extensively for the control of army worm (Pseudaletia separata and Persectania aversa) in New Zealand.

\section{RESIDUAL ACTION}

Many of the factors that influence speed of action will also influence residual action. In the tests shown in Table 2 nicotine was used to rid apple trees of aphids. They were then sprayed with different insecticides and the rate of infestation from neighbouring trees was recorded. This experiment shows that Aphis pomi is definitely susceptible to carbaryl.

TABLE 2: RATE OF INFESTATION BY APHIS POMI

FOLLOWING NICOTINE FUMIGATION OF TEST TREES

\begin{tabular}{|c|c|c|c|c|c|}
\hline \multirow{2}{*}{\multicolumn{2}{|c|}{$\begin{array}{l}\text { Insecticide and } \\
\text { Rate per } 100 \text { gal }\end{array}$}} & \multicolumn{4}{|c|}{ Aphids per 100 leaves } \\
\hline & & 0 day & 14 days & 22 days & 25 days \\
\hline Carbaryl 50W P $2 \mathrm{lb}$ & & 0 & 46 & 144 & 480 \\
\hline Carbaryl 50W P $1 \mathrm{lb}$ & ....... & 0 & 56 & 17 & 760 \\
\hline Diazinon $25 \mathrm{~W}$ P $2 \mathrm{lb}$ & $\ldots . . .$. & 0 & 557 & 3,500 & 9,700 \\
\hline Untreated ....... & ....... & $\ldots . . .$. & 3,600 & 3,900 & 13,000 \\
\hline
\end{tabular}

In Table 3, apples were sprayed under field conditions and brought into the laboratory where eggs of the codling moth were placed on them. The number of live larvae which actually penetrated the apple was recorded. The number of days indicates the time between spraying in the field and removal of the apple from the tree.

TABLE 3: SURVIVAL OF CODLING MOTH LARVAE ON TREATED APPLES

\begin{tabular}{|c|c|c|c|c|c|}
\hline \multirow{2}{*}{$\begin{array}{l}\text { Insecticide and } \\
\text { Rate per } 100 \text { gal }\end{array}$} & & \multicolumn{4}{|c|}{$\begin{array}{l}\text { No live larvae per apple } \\
\text { after weathering }\end{array}$} \\
\hline & & 1 day & 14 days & 21 days & 28 days \\
\hline 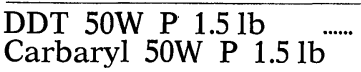 & $\ldots \ldots . .$. & $\begin{array}{ll}\ldots \ldots . . & 0 \\
\ldots . . . . & 0\end{array}$ & $\begin{array}{l}1 \\
0\end{array}$ & $\begin{array}{r}1.4 \\
0\end{array}$ & $\begin{array}{l}5.1 \\
1.3\end{array}$ \\
\hline
\end{tabular}

This information on the residual life of carbaryl can be summarized by saying that, under most conditions, satisfactory residuals are obtained. In New Zealand, it is the practice to spray apples on a 10- to 14-day schedule and under these conditions carbaryl provides excellent control. In some areas, perhaps in Central Otago where fruit is irrigated and the climate is hot and dry, a very good control could be obtained by applying at intervals of 21 to 28 days.

\section{LENGTH OF RESIDUAL}

While residual control with carbaryl will vary greatly, depending upon the dosage, weathering, plant growth, and the insect involved, it may be considered quite good in comparison with other insecticides now available. Orchard spray programmes directed against codling moth are completely effective applied at 10- to 14-day intervals in humid areas, and at 21- to 30-day intervals in dry irrigated country. An example of the excellent duration and residual toxicity can be seen in Table 4 .

TABLE 4: MORTALITY OF THE PINK BOLLWORM (PECTINOPHORA GOSSYPIELLA) AFTER EXPOSURE TO AGED RESIDUES UNDER LABORATORY CONDITIONS

\begin{tabular}{|c|c|c|c|c|c|c|c|c|}
\hline \multirow{2}{*}{\multicolumn{3}{|c|}{$\begin{array}{l}\text { Chemical at } \\
20 \mathrm{mg} / \mathrm{sq} \text {. } \mathrm{ft}\end{array}$}} & \multicolumn{6}{|c|}{$24 \mathrm{hr}$ Percentage Mortality of Moths on } \\
\hline & & & & 1 day & $\begin{array}{r}K \\
5 \text { days }\end{array}$ & $\begin{array}{l}\text { sidues a } \\
8 \text { days }\end{array}$ & 16 days & 25 days \\
\hline Carbaryl & $\ldots . . .$. & $\ldots . . . \cdot$ & & $\begin{array}{r}80 \\
100\end{array}$ & $\begin{array}{l}100 \\
100\end{array}$ & $\begin{array}{r}60 \\
100\end{array}$ & $\begin{array}{l}20 \\
90\end{array}$ & $\begin{array}{r}10 \\
100\end{array}$ \\
\hline
\end{tabular}


It can be said that, as normally used against insect pests and on crop plants, carbaryl provides a residual effect longer in duration than most phosphate insecticides and equivalent to most chlorinated hydrocarbons.

\section{EFFECT OF TEMPERATURE}

The effect of temperature on the insecticidal activity of carbaryl is similar to that observed with other insecticides; namely, with increasing temperature a somewhat increased response is noted. This has been borne out again with the use of carbaryl in comparison with other insecticides for the control of army worm, where it has been noted that there is a higher degree of control at the recommended dose rate of 0.75 to $1 \mathrm{lb}$ a.i. per acre when the air and soil temperatures are high.

$$
\text { TOXICOLOGY }
$$

Laboratory investigations of carbaryl toxicology have been carried out by the Mellon Institute for Industrial Hygiene, U.S.A. Preliminary studies began in 1953, and final intensive studies were made in 1956 and extended through to 1958. The acute oral L.D.50 values have been obtained for common laboratory animals and are shown in Table 5 .

TABLE 5: ACUTE ORAL TOXICITY OF CARBARYL (LD.50) $m g / k g$

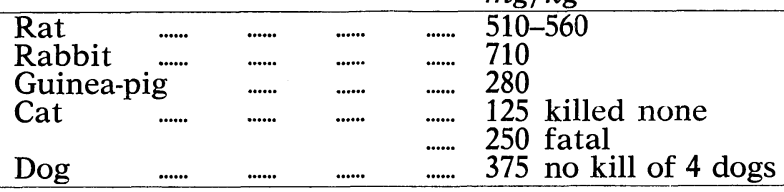

In this work carbaryl was ministered as a $5 \%$ suspension in $0.25 \%$ agar. Comparative acute oral toxicity data relate carbaryl to other pesticides in Table 6. Skin penetration tests on rabbits show carbaryl definitely not hazardous by this route. Rabbits tolerate $2000 \mathrm{mg} / \mathrm{kg}$ of body weight in dimethylphthalate (B) and $5000 \mathrm{mg} / \mathrm{kg}$ per body weight in a $40 \%$ aqueous suspension (A). Compared with other pesticides, carbaryl obviously has a low hazard by this route.

TABLE 6: RABBIT SKIN PENETRATION - COMPARATIVE

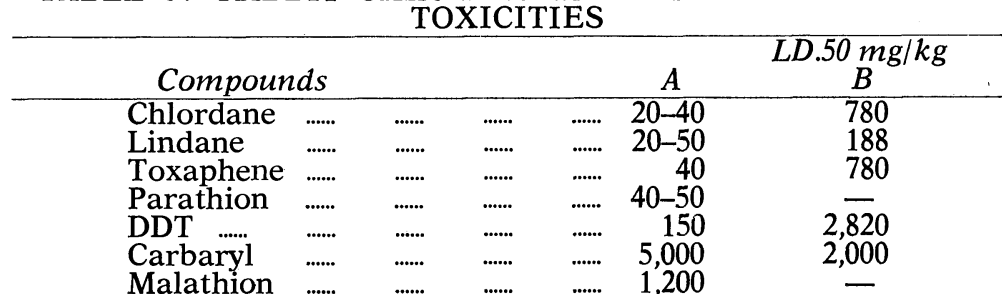

Inhalation studies show that guinea-pigs can tolerate heavy dust clouds of carbaryl. In this test a 4-hour exposure period was used. No symptoms other than lachrymation resulted from the exposures.

Chronic toxicity studies again show a relatively low order of animal response to this insecticide. For two years carbaryl was included in the diet of rats at different levels. No significant effect on their health was noted at a feeding level of 200 p.p.m., equivalent to a continuous daily ingestion of about $8 \mathrm{mg} / \mathrm{kg}$. Similar tests were run on dogs over a one-year period. No effect was noted at a feeding level of 400 p.p.m. or about $7.2 \mathrm{mg} / \mathrm{kg}$ daily. Observations were made on body weight, weight of liver and kidney and the micropathology of numerous organs. Comparison of the "no effect" levels of various pesticides are given in Table 7. 
TABLE 7: COMPARATIVE CHRONIC TOXICITY OF INSECTICIDES - "NO EFFECT" LEVEL IN TWO-YEAR RAT TEST

\begin{tabular}{|c|c|c|c|c|c|c|}
\hline Insecticide & & & & & & $m g / k g / d a y$ \\
\hline Chlordane ...... & ....... & ....... & ....... & ........ & & 0.125 \\
\hline DDT & $\ldots . . . .$. & $\ldots . . .$. & $\ldots . . .$. & $\ldots . . .$. & $\ldots . . .$. & 0.25 \\
\hline Toxaphene & $\ldots . . .$. & $\ldots . . .$. & $\ldots . . .$. & $\ldots . . .$. & $\ldots . . .$. & 5.0 \\
\hline Lindane & $\ldots . . .$. & $\ldots . . . .$. & $\ldots . . .$. & $\ldots . . .$. & $\ldots . . .$. & 5.0 \\
\hline Methoxychlor & ....... & $\ldots . . .$. & ....... & $\ldots . . .$. & $\ldots . .$. & 10.0 \\
\hline Carbaryl ....... & ........ & ........ & $\ldots . . . .$. & $\ldots . . .$. & $\ldots . . .$. & $10+$ \\
\hline Melathion & & $\ldots . . .$. & $\ldots . . .$. & $\ldots . . .$. & $\ldots . .$. & $100+$ \\
\hline
\end{tabular}

Other standard tests show a similar pattern for carbaryl toxicology. These include eye irritations, skin sensitization, subcutaneous, intraperitoneal and intravenous injections.

\section{MODE OF ACTION}

On the experimental animals the action of carbaryl is clearly that of a mild, moderate cholinesterase inhibitor. It is not as potent an enzyme inhibitor as compounds such as parathion and malathion Large intravenous and oral doses of carbaryl produce symptoms typical of excessive stimulation of the parasympathetic nervous system. Atropine sulphate controls these symptoms almost perfectly, and permits the animal to tolerate much higher dosages than is otherwise possible. There has been no experience of human illness resulting from accidental exposure to carbaryl. If symptoms occur, they should closely follow those caused by other anti-cholinesterases.

\section{ACKNOWLEDGEMENT}

The writer acknowledges assistance from Union Carbide International Co. 